\title{
Die leerteorieë onderliggend aan inligting en kommunikasietegnologie waarvan onderwysers kennis moet dra
}

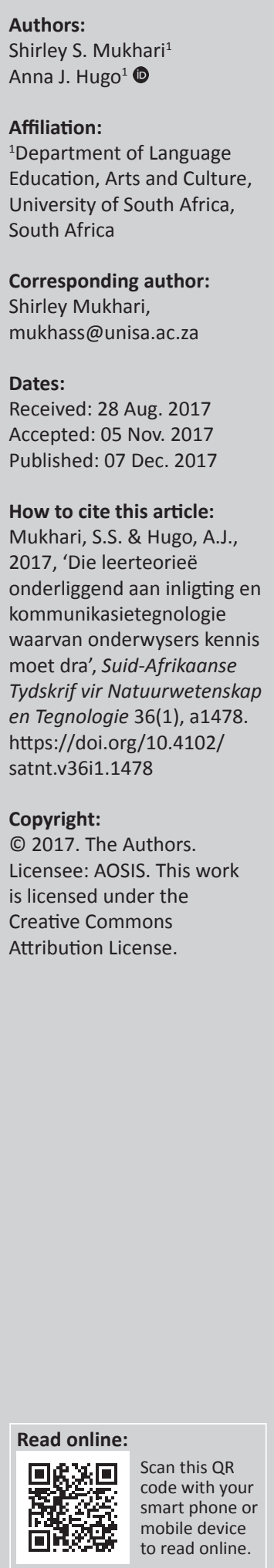

In hierdie artikel word die data uit 'n navorsingsprojek oor die gebruik van inligting en kommunikasietegnologie (IKT) in skole bespreek. Gebaseer op die terugvoering wat van die respondente verkry is, is die navorsers van mening dat onderwysers vertroud moet wees met die leerteorieë onderliggend aan die gebruik van IKT in die klaskamer. Behaviourisme, konstruktivisme en konnektivisme as teorieë onderliggend aan IKT word bespreek. Daar word aangedui hoe kennis van hierdie drie leerteorieë saam met die gebruik van IKT tot voordeel van onderrig en leer in die klaskamer kan strek.

The learning theories in regard to information and communication technology that teachers need to know. In this article, the data obtained from a research project about the use of Information and Communication Technology (ICT) in schools is discussed. Based on the feedback from the respondents, the researchers opine that teachers have to be acquainted with the learning theories underlying the use of ICT in the classroom. Behaviorism, constructivism and connectivism as underlying theories for ICT are discussed. It is deliberated how knowledge of these three learning theories in conjunction with the use of ICT could benefit teaching and learning in the classroom.

\section{Inleiding}

Onderwysers is die hoofagente om inligting en kommunikasietegnologie (IKT) met sukses in die onderrig- en leersituasie te integreer. Die vooruitgang in die gebruik van IKT in die klaskamer berus op die betrokkenheid en bereidwilligheid van die onderwyserskorps om dit te doen. Eze en Olusola (2013:6) verduidelik ook dat die rol van die onderwyser in die klaskamer besig is om te verander omdat daar deur IKT nuwe rolle vir onderwysers geskep word. Wanneer IKT gebruik word, word tru-projektors en skryfborde oorbodig en verouderd, veral as die leerders toegang tot dieselfde netwerkbronne as die onderwysers het. Onderwysers se rol in die klaskamer as diegene wat kennis oordra, verander tans ook omdat leerders aangemoedig word om hulle kennis self te konstrueer. Sodoende raak die leerders betrokke by kritiese denke en leer hulle om die internet te gebruik om inligting wat benodig word te soek en te kies.

In die nuwe eeu word samewerking tussen klasmaats aangemoedig en leer die leerders om mekaar te onderrig waar nodig. Dit word van die moderne leerder verwag om kennis met ander leerders te deel, en sodoende word sosiale interaksie bevorder. Hierdie samewerking en die deel van inligting kan samewerkende leer en groepwerk bevorder (Taole, Mukhari \& Hugo 2016:189). Sodoende word gemeenskappe van leer geskep.

Die vraag ontstaan of onderwysers in Suid-Afrika gereed is om IKT in die klaskamer tot sy reg te laat kom. Onderwysers benodig nie net voldoende kennis en goeie opleiding in die gebruik van IKT in die klaskamer nie, maar hulle moet ook die teoretiese onderbou van die gebruik van IKT vir onderrigdoeleindes verstaan. Soos in alle onderrigsituasies behoort onderwysers te weet watter leerteorieë in die wyse waarop hulle onderrig gee van toepassing is wanneer IKT-onderrig gebruik word.

\section{Agtergrond en probleemstelling}

Verskillende outeurs beskryf IKT as die gereedskap wat help om inligting elektronies en met kommunikasiemiddele soos rekenaars, telefone, selfone, televisie, radio's en kameras te versprei. IKT kan ook gesien word as gerekenariseerde en elektroniese gereedskap wat menslike interaksie 
vereis om persoonlike, formele en sakepraktyke uit te voer (Magano \& Ramnarain 2015:93).

Die verskillende IKT-gereedskap wat op die Suid-Afrikaanse mark beskikbaar is, is skootrekenaars, persoonlike rekenaars, selfone, skryfborde en tablette. Dit lyk asof tablette hoog in aanvraag is omdat hulle so maklik vervoer kan word. Mdlongwa (2012:4) wys ook daarop dat daar baie uitdagings is om die gebruik van IKT in skole in Suid-Afrika uit te brei. Desondanks word dit in talle skole met sukses gebruik.

Daar bestaan egter ook ' $n$ groot behoefte om die gebruik van IKT in Suid-Afrikaanse skole uit te brei, juis omdat verskillende studies aangetoon het dat IKT positief bydra tot persoonlike en ekonomiese ontwikkeling, en die strewe na lewenslange leer. Lee (2011:3) wys op die belangrikheid van IKT wat die vertrekpunt kan wees om seker te maak dat alle mense toegang tot goeie kwaliteit onderwys kry. Hierdie onderwys moet ook relevant wees vir die tydvak waarin ons leef. Daar word aanvaar dat die mens tans in die tydperk van die vierde nywerheidsrewolusie is en IKT die een manier is waarop mense van oraloor verbind kan bly.

In hierdie artikel word drie van die vernaamste leerteorieë wat onderliggend aan die gebruik van IKT in die klaskamer van skole is, bespreek. Die skrywers van die artikel is van mening dat die integrering van IKT in die onderrig-leersituasie aan die hand van die beginsels van sekere leerteorieë moet geskied. Die eerste leerteorie wat ingesluit word, is behaviourisme. Hierdie leerteorie word ingesluit juis omdat onderwysers steeds soms onderrig gee asof hulle die enigste bron van kennis is. Dit word ook bespreek omdat behaviourisme vir die onderrig van sekere leerinhoud, met behulp van IKT gebruik kan word, veral wanneer dit by drilwerk kom. Neobehaviourisme het uit behaviourisme voortgevloei, maar daar is nie 'n duidelike skeidslyn tussen behaviourisme en neobehaviourisme nie. Neobehaviourisme word soos behaviourisme hoofsaaklik geassosieer met die werk van Skinner.

Konstruktivisme word bespreek omdat hierdie leerteorie aantoon dat onderwysers die verwerwing van kennis deur hulle leerders, onder meer, met behulp van IKT moet ondersteun en al die nuwe kennis nie noodwendig moet oordra nie. Die belangrikheid van konneksies wat gevorm moet word om inligting tussen leerders en netwerke oor te dra, kom in konnektivisme na vore. Derhalwe sal konnektivisme ook bespreek word omdat dit aantoon dat leer plaasvind wanneer daar interaksie tussen groepe is en IKT juis geskik is vir vinnige interaksie tussen mense en groepe.

Die belangrikheid van leerteorieë het geblyk uit navorsing waarby 'n groep onderwysers betrek is. Die inligting wat gedurende die onderhoude met die onderwysers verkry is, het die noodsaaklikheid van kennis van die leerteorieë na vore laat kom. Om te leer is nie 'n eenvoudige proses nie. Hoe meer diegene wat onderrig gee, weet van leer en die verskillende leerteorieë, hoe beter is hulle toegerus om die leerproses van hulle leerders te ondersteun. Die beginsels van leer, gebaseer op verskillende studies van die leerproses deur sielkundiges wat tot die onderskeie leerteorieë gelei het, moet aan onderriggewers bekend wees. Diegene wat onderrig gee, moet volgens Ertmer en Newby (2013:45) nie net een leerteorie ken en toepas nie, maar moet weet watter leerteorie se beginsels in elke opvoedkundige onderrigsituasie van belang is.

\section{Etiese oorwegings}

Etiese klaring om die navorsing te doen is van die Gautengse Onderwysdepartement verkry en elkeen van die tien respondente het ook skriftelike toestemming verleen.

\section{Die navorsingsprojek en die hoofnavorsingstemas}

Die data wat in hierdie artikel gebruik word, is verkry tydens 'n navorsingsprojek in 'n woonbuurt in die groter Tshwanemunisipaliteit. In hierdie woonbuurt is daar beide formele en informele behuising. Die leerders wat die skole bywoon, kom dus uit huise waar daar nie 'n gebrek aan alledaagse noodsaaklikhede is nie, asook uit huise waar daar armoede is. Ses onderwysers en vier skoolhoofde het as respondente gedien en hulle was aan beide primêre en sekondêre skole verbonde. Die skole is spesifiek gekies omdat daar IKTfasiliteite is. Die onderhoude het gegaan oor die benutting van IKT in die klaskamer en in die skole, en oor watter uitdagings die respondente met die gebruik van IKT ervaar, asook die voordele wat die gebruik van IKT inhou.

Daar is individuele onderhoude met die deelnemers gevoer en die onderhoude is op band opgeneem. Dit is later getranskribeer sodat die navorsers die temas wat uit die navorsing geblyk het, kon bepaal.

Omdat die data uit onderhoude verkry is, is die navorsing kwalitatief van aard. Die onderhoude het die navorsers in staat gestel om die inligting van mense in hulle natuurlike, alledaagse werklikheid te verkry. Elke mens sien en beleef die werklikheid anders en daar is dus verskillende weergawes van die werklikheid wat nagevors moet word. Ook in 'n skoolsituasie is daar verskillende weergawes van die werklikheid en dit sluit die gebruik van IKT in die klaskamer in (Krauss 2005:760). Die onderhoude het die navorsers gehelp om die werklikheid in die skoolsituasie soos gesien deur die oë van die respondente te herskep. Sodoende kon die respondente se menings oor die faktore wat die gebruik van IKT in die klaskamer beïnvloed, vasgestel word. Die navorsing het vertrek vanuit die sosiale konstruktivisme. Navorsers wat hierdie tipe epistomologie gebruik, vra vrae soos waarmee mense hulle besig hou, hoe hulle sekere aktiwiteite doen, wat die doel van die aktiwiteite is en wat dit vir die mense beteken. Só raak navorsers bewus van die betekenis, simboliek, oortuigings, idees en gevoelens wat aan voorwerpe, aktiwiteite of ander persone binne ' $n$ bepaalde werklikheid gegee word (Bailey 2007:53).

Nadat die navorsers intensief deur die getranskribeerde onderhoude gewerk het, het dit geblyk dat sommige van 
die temas verbind kan word aan die skoolhoofde en die onderwysers. Die ander temas is op skoolvlak of is gekoppel aan die provinsiale Departement van Onderwys. Daar is egter nie deur die respondente na die leerders verwys nie. Tog is dit noodsaaklik dat vandag se leerders IKT moet bemeester, veral met die oog op 'n moontlike beroep later in hulle lewens. 'n Aantal temas het uit die data na vore gekom, maar in hierdie artikel word daar slegs na drie van die temas verwys omdat hierdie temas nou aansluit by leerteorieë. Die temas dui daarop dat onderwysers in die onderrig van en gebruik van IKT kennis moet dra van die toepaslike leerteorieë.

Die meeste van die respondente het hulle bekommernis oor 'n gebrek aan ouerlike betrokkenheid in die skole waar hulle werk, uitgespreek. Weens armoede en ook ongeletterdheid het baie van die kinders geen toegang tot IKT of rekenaars by die huis nie. Een van die onderwysers het egter melding gemaak van die positiewe manier waarop sy ouers inspan om hulle kinders te help om IKT te gebruik. Sy vra die ouers soms om hulle kinders toe te laat om klein opdragte op die ouers se slimfone uit te voer. So sien die ouers dat die gebruik van IKT hulle kinders opvoedkundig help, en die onderwyseres het gehoop dat dit die ouers sal aanmoedig om hulle kinders van toepaslike IKT te voorsien as dit binne hulle vermoëns is.

Aangesien hierdie tema melding maak van klein opdragte wat met behulp van IKT op slimfone uitgevoer kan word, val dit binne die raamwerk van behaviourisme, want leerders kan met behulp van die slimfoon geassesseer word om te sien of hulle verstaan wat in die klas verduidelik is. Dit sou ook by konstruktivisme aansluiting kon vind, want daar kan van leerders verwag word om deur die opdragte nuwe kennis te konstrueer.

Sommige van die respondente was wel positief oor die gebruik van IKT en het die voordele daarvan in die klaskamer vermeld. Wat die leerders betref, het hulle veral melding gemaak van die motiverende waarde van die gebruik van IKT in die klaskamer en aangedui hoe dit help om die leerders geïnteresseerd te hou. Hulle het gemeld dat die leerders dit geniet om inligting op die internet te soek en te kry. Dit het leerders toegelaat om teen hulle eie spoed te werk, maar ook om saam te werk en in groepsverband te werk. Deur die regte gebruik van IKT kan leerders bemagtig word om wat hulle aanleer, self te reguleer. Sodoende kan die leerproses volgens die leerders se behoeftes aangepas word en kan bepaalde doelwitte steeds bereik word. Die motiveringswaarde wat daar in die gebruik van IKT is, moet in gedagte gehou word.

Hierdie tema wat uit die navorsing geblyk het, vind aansluiting by beide konstruktivisme en konnektivisme.

Van die respondente het melding gemaak van die persoonlike voordele wat die gebruik van IKT vir hulle het. IKT help hulle om meer opgedateerde inligting te bekom en dit dra by tot hulle persoonlike en professionele ontwikkeling. Deur met behulp van die internet deel te neem aan leergemeenskappe, word hulle bemagtig met die inligting en kennis wat hulle benodig om suksesvol in hulle beroepe te wees.

Die ontwikkeling van leergemeenskappe val binne die raamwerk van konnektivisme en dit is juis iets wat van groot waarde vir professionele mense soos onderwysers en hulle professionele ontwikkeling is.

\section{Die benutting en noodsaaklikheid van leerteorieë in die klaskamer met inligting en kommunikasietegnologie}

Watter teoretiese raamwerk in ' $n$ klaskamer van toepassing is, sal afhang van die leerinhoud, die omstandighede, die konteks waarbinne die onderrig geskied en die ontwikkelingsvlak van die leerders. Wat egter vasstaan, is die feit dat daar in die moderne klaskamer wegbeweeg sal word van Skinner se behavioristiese teorie. Volgens hierdie teorie word dit nie van leerders verwag om hulle eie kennis te konstrueer nie, maar is die onderwysers die persone wat die kennis en leerinhoud oordra. Die leerders bly dus afhanklik van die onderwysers se verduidelikings, terwyl die onderwysers die leerders se kennis deur gereelde assessering versterk. Wanneer IKT korrek en met oordeel in die klaskamer gebruik word, kan die beginsels van behaviourisme, asook die beginsels van ander leerteorieë met sukses deur onderwysers benut word.

\section{Behaviourisme}

Behaviourisme, soos wat dit in onderrig en leer gebruik word, word gekenmerk deur sekere tegnieke en beginsels. Onderrig word beskou as 'n proses waartydens inligting aan passiewe leerders oorgedra word. Onderwysers wat volgens die behaviouristiese beginsels onderrig, weet watter stappe gevolg moet word om leerders te onderrig, wat die uitkomste moet wees en watter faktore in die omgewing gemanipuleer moet word om leer te bevorder, om assessering te vergemaklik en om gedrag te verander. Volgens die behaviourisme is dit onderwysers se rol om te onderrig en word hulle beskou as die vakkenners en die hoofbronne van kennis vir die leerders. (Brown 2006:110). Onderrig word volgens die behaviouriste gesien as gedrag, oftewel leer, wat gevorm moet word. Die behaviouristiese teorieë neem egter, volgens Schunk, nie kognitiewe faktore in ag nie, ook nie die invloed van plaasvervangende leer, soos waarneem, lees en luister, nie (Belford 2013:150).

'n Ander aspek wat deur Schunk uitgelig word binne die konteks van behaviourisme, is geheue. Dit is nie direk deur die behaviouriste aangeroer nie. Die aanleer van gewoontes en kennis word bespreek, maar daar word nie verwys na hoe hierdie gewoontes en kennis geberg moet word vir toekomstige gebruik nie. As inligting nie gebruik word nie, word dit vergeet. Derhalwe het Schunk beklemtoon dat inoefening en 'n oorsig van werk wat gedoen is, periodiek moet plaasvind (Ertmer \& Newby 2013:45). In die onderrigleersituasie is hierdie beginsel van belang. 
Onderwysers is diegene wat besluit wat onderrig word en watter stappe gevolg sal word om sekere kennis aan die leerders oor te dra. Opvoedkundige aktiwiteite vind gevolglik plaas vanuit die perspektief van die onderwysers en die sterk punte van die onderwysers, asook hulle voorkeure en onderrigstyle, wat veroorsaak dat die onderrigsituasie onderwysergesentreerd is (Dede 2008:45-46).

IKT wat op behaviouristiese beginsels berus, kan deesdae steeds gebruik word om feite, inligting en vaardighede wat in die inhoud van verskillende vakgebiede bemeester moet word, aan te leer (Dede 2008:46). Die gebruik van IKT gebaseer op behaviourisme kan met sukses in programme wat parate kennis van leerders vereis, benut word. Sekere taalvaardighede, soos die aanleer van spelwoorde in die huistale en in addisionele tale, kan met behulp van rekenaarprogramme ingedril word. Daar is programme beskikbaar wat byvoorbeeld die regte uitspraak van woorde in Engels onderrig. Sorg moet net gedra word dat die programme die Britse uitspraak insluit. Die THRASS (Teaching Handwriting, Reading and Spelling) -program word byvoorbeeld in sommige skole in Suid-Afrika gebruik. Dit is ' $n$ rekenaarprogram wat die ingewikkelde foniese stelsel van Engels met klank en prentjies verduidelik (Place 2016:66-67). Die toepassing van behaviourisme maak dit ook geskik vir ander drilwerk wat in skole steeds nodig is, soos byvoorbeeld die leer van tafels of die doen van vinnige hoofrekene. Daar is ook opvoedkundige programme beskikbaar wat gerig is op probleemoplossing of die praktiese toepassing van kennis wat op behaviourisme berus. By die keuse van IKT-programme behoort onderwysers seker te maak watter leerteorie onderliggend aan die program is.

Die gebruik van IKT-programme wat op behaviouristiese beginsels geskoei is, hou ook ander voordele in. Hierdie tipe programme gee onmiddellike terugvoering - dit is iets waaraan die huidige jong generasie gewoond is en waarna hulle verlang. IKT-programme het groot motiveringswaarde. Die respondente wat in die navorsing gebruik is, het juis melding gemaak van die waarde van IKT vir motivering in die onderrigsituasie.

Die gebruik van IKT wat op behaviouristiese beginsels berus, is ook uiters geskik vir gedifferensieerde onderwys of onderrig op verskillende vlakke. Daar word deesdae na multivlak-onderwys verwys. Dit pas dus goed in by die beginsels van insluitende onderwys. Die voordele van multivlak-onderwys is dat leerders teen hulle eie pas en volgens hulle unieke vermoëns kan werk. Leerders kry die kans om onafhanklik te werk, terwyl kompetisie met ander leerders, wat dikwels nadelig is vir leerders wat akademies nie goed vorder nie, beperk word. Leerders word egter op die vlakke waartoe hulle in staat is, uitgedaag (Engelbrecht 2013:46). Met behulp van die regte IKT-programme kan elke leerder gehelp word om sekere vakinhoude wat aangeleer moet word, te bemeester.

Tydens die navorsing het dit geblyk dat kinders in die meeste van die primêre skole van rekenaars leer, want dit is ' $n$ vak in die kurrikulum. Hierdie leerproses het hoofsaaklik aan die hand van behaviourisme plaasgevind. Dit kan lei tot passiewe deelname van die leerders. Dit sluit aan by Dede (2008:46) se mening dat leerders wat deur middel van die behaviouristiese onderrigbenadering onderrig word, passief is en dat hulle verstandelike vermoëns, wat moet verseker dat leer plaasvind, nie in ag geneem word nie. Gevolglik is die behaviouristiese benadering tot die onderrig en gebruik van IKT in die skoolklaskamer nie die enigste benadering wat benut moet word nie.

\section{Konstruktivisme}

Konstruktivisme is 'n leerteorie wat ná behaviourisme ontstaan het. Hierdie leerteorie beklemtoon interaksie, betekenisverkryging en die konstruksie van kennis deur individuele leerders of groepe leerders. Schunk reken selfs dat konstruktivisme meer van 'n epistomologie as 'n teorie is omdat die idee van wetenskaplike waarheid verwerp word. Maar wat van belang in die onderrigsituasie is, is die feit dat Schunk dit stel dat elke persoon sy of haar eie kennis konstrueer, met die gevolg dat wat vir een persoon waar is, dalk nie noodwendig waar vir ' $n$ ander persoon is nie (Belford 2013:150).

Volgens die teorie van konstruktivisme word leer gesien as 'n aktiewe proses en die doel van onderrig om die konstruksie van kennis te ondersteun eerder as om kennis oor te dra. Konstruktivisme onderskei tussen kognitiewe en sosiale konstruktivisme.

Volgens Wang (2008:413) is konstruktivisme 'n persoon se konstruktivistiese aktiwiteit wanneer hy of sy sin van die wêreld probeer maak. In kognitiewe konstruktivisme is die klem op die individu in die groep. Kennis geskied en word verwerf in die kop van elke persoon in die groep. Aan die ander kant, beskou sosiale konstruktiviste kennis nie net as 'n verstandelike aktiwiteit nie, maar sien hulle kennis as 'n verband tussen kulturele en sosiale prosesse wat 'n rol speel om kennis in beweging te bring en te beïnvloed. Vygotsky (1978), wat met die idee van sosiale konstruktivisme begin het, het die belangrikheid van die kulturele en sosiale konteks waarbinne leer plaasvind, beklemtoon.

Beide rigtings van konstruktivisme, naamlik kognitiewe konstruktivisme en sosiale konstruktivisme, kan in die leerproses in die skool gebruik word. Sosiale konstruktivisme beklemtoon die interaksie van leerders met hulle klasmaats en ouderdomsgenote in die skool, en ook hulle onderwysers en ouers. Tegnologie is van belang om leerders te help om hulle verstandelike vermoëns te verbeter en om kennis saam te stel. Die rol van die onderwysers is om fasiliteerders te wees wat hulle onderrigmetodes op so 'n wyse met IKT behoort te kombineer dat leerders beter kanse gegee word om kennis op te bou, om verstandelike prosesse van 'n hoër orde te ontwikkel en om samewerking met ander leerders uit te bou. Kognitiewe konstruktivisme lei daartoe dat leerders deur interaksie met hulle omgewing kreatiwiteit en denkvaardighede ontwikkel wat hulle in staat stel om 'n eie 
persoonlike siening van die wêreld te skep. Só kry leerders die geleentheid om deur middel van die gebruik van IKT betrokke te raak by betekenisvolle en werklike leer. Konstruktiviste stem juis saam dat leerders leer wanneer hulle iets doen en self betrokke is (Gunter \& Gunter 2015:266). 'n Ander beginsel van konstruktivisme is dat leerders hul eie kennis konstrueer wanneer hulle nuwe inligting met bestaande kennis verbind. Felix (2005:88) stem hiermee saam, want hy is van mening dat mense die beste deur hul eie ervarings leer. Nuwe kennis word dan gesien en beoordeel in terme van hulle persoonlike en bestaande ervarings.

Wanneer leer volgens die konstruktivistiese benadering plaasvind, word dit opgebou en nie oorgedra nie. Onderwysers word nie as die enigste bron van kennis gesien nie en hul rol is om leerders te help om hul vaardighede ten volle te gebruik wanneer hulle leer. Die onderwyser vervul dus 'n rol as 'n fasiliteerder, 'n afrigter en 'n motiveerder (Kler 2014:267). Onderwysers moet egter weet hoe om die konstruktivistiese benadering te vervang met die direkte onderrigbenadering wanneer dit nodig is om aan die leerders byvoorbeeld sekere reëls en basiese kennis te verduidelik wat nodig is vir kreatiwiteit, probleemoplossing en leer.

Uit die navorsing het dit geblyk dat sommige van die onderwysers wat respondente was, baie bewus daarvan is dat IKT gebruik kan word in die klaskamer om leerders in staat te stel om hulle eie leerproses te reguleer en om nuwe kennis te kan konstrueer. Hulle het dus besef dat hulle die fasiliteerders van hul leerders se leerproses kan wees en ook dat IKT moontlik groot motiveringswaarde in die klaskamer kan hê. Om self kennis op te bou, is een van die beginsels van Uitkomsgebaseerde Onderwys en is ook in die nuwe Kurrikulum en Assesseringsbeleidsverklaring van die Departement van Basiese Onderwys vervat. Die respondente het egter aangedui dat hulle nie weet wanneer om bloot met behulp van IKT 'n konstruktivistiese benadering in die klas te volg en wanneer om net die direkte onderrigbenadering te gebruik nie. Geeneen van die respondente het verwys na IKT en hul leerders in die klaskamer nie. Derhalwe is daar nie bewys dat hulle die leerders aangemoedig het om hul nuwe kennis op te bou aan die hand van hul eie ervarings nie. As leerders bemagtig word om hul leer met behulp van IKT te reguleer, kan die leerproses aangepas word volgens die individuele behoeftes van elke leerder. Wat die leerders betref, is sosiale konstruktivisme en die gebruik van IKT nie ten volle in die klaskamers van die respondente benut nie.

\section{Konnektivisme}

Konnektivisme word beskou as die leerteorie van die digitale era. Die derde millennium word gekenmerk deur 'n wêreld wat vinnig verander en saam daarmee nuwe tegnologie wat steeds aangepas en verbeter word. Konnektivisme het ontstaan omdat daar 'n verduideliking gegee moes word van hoe studente in die 21ste eeu leer. Hierdie leerteorie is deur Siemens uitgebrei. Hy was van mening dat die tradisionele leerteorieë nie meer relevant in die huidige eeu is nie omdat inligting en kennis gedurig verander en uitbrei (Brooks
2015:28). Deur die gebruik van IKT is 'n magdom kennis aan leerders beskikbaar en word dit nie beïnvloed deur afstand, tyd en geografiese grense nie (Garcia, Brown \& Elbeltagi 2013:253). In die era van tegnologie is studente, en ook leerders op skool, lankal in staat om met inligting om te gaan en om met behulp van tegnologie saam te werk. Dunaway (2011:678) meen tereg dat die internet en tegnologie leerlandskappe so verander het dat '...learning landscapes are networked, social and technological'. Konnektivisme erken dus die invloed van die digitale tydperk. Leer geskied nou ook tussen veranderende persoonlike netwerke van kennis, en die huidige leerders is in staat om verbindings met die verskillende netwerke te maak. Konnektivisme beklemtoon dan juis die belangrikheid van die verbindings tussen die verskillende inligtingbronne. Hierdie leerteorie verwerp die tradisionele idee dat leer uitsluitlik binne-in 'n persoon plaasvind (Brooks 2015:27-28)

Volgens Siemens (2004:1) is konnektivisme 'n leerteorie wat steeds die konstruksie van kennis insluit. Maar konnektivisme wys op die belangrikheid van persone, en dus ook van leerders wat konneksies vorm om inligting tussen die leerders en lede van hulle netwerke te versprei. Deur hierdie interaksie vind leer plaas wanneer klasmaats en ouderdomsgenote saamwerk, menings deel en kritiek uitspreek deur die gesprekke wat hulle voer.

Siemens was die persoon wat konnektivisme eerste beskryf het. Volgens hom wys konnektivisme hoe leerders leer met behulp van kennis wat deur die gebruik van persoonlike netwerke verkry is. Hierdie nuwe leerteorie verwerp nie die ou leerteorieë nie, maar speel 'n groot rol om nuwe ontwikkelings te verduidelik wat nie in die ou leerteorieë aangedui is nie. Dié teorie bou op reeds bestaande kennis soos die behoefte aan spesifieke, kognitiewe vaardighede om inligting suksesvol te verwerk. Konnektivisme beklemtoon egter die belangrikheid van netwerke vir verbindings en toegang tot opgedateerde kennis. Konnektivisme is sosiotegnologies van aard. Dit bied aan onderwysers en leerders die geleentheid om in verbinding met mekaar te kom. Só word netwerke van leergemeenskappe en leerplatforms gevorm wat mense help om toegang te verkry tot opgedateerde kennis en om saam te dink en idees te deel (Kop \& Hill 2008:1; Siemens 2004:2). Konnektivisme as 'n leerteorie kan ' $n$ impak hê op onderrig en leer omdat IKT die sosiale media bied vir die skep van netwerke en verspreiding van inligting aan die lede van netwerke.

Net soos die ouer leerteorieë, kan aan die hand van konnektivisme verduidelik word hoedat die leerproses in die IKT omgewing plaasvind. Konnektivisme word beskou as 'n denkrigting wat baie bruikbaar is vir die gebruik van tegnologie in die hedendaagse klaskamer. Dit is deel van die moderne sosiale leerproses wat op webwerwe beskikbaar is. Die samelewing verander vinnig en konnektivisme stel mense in staat om na te dink oor al die nuwe idees en kennis wat met die vinnig veranderende tegnologie orals in die wêreld beskikbaar gestel word. Wat konnektivisme so belangrik maak, is die feit dat dat dit spesifieke tegnologiese 
geleenthede aan leerders bied om self betrokke te raak by die massa kennis waartoe mense toegang het (Duke, Harper \& Johnston 2013:7-9).

Navorsing dui daarop dat onderwysers sentraal staan om te verseker dat IKT in die onderrig en leersituasie geïntegreer word. Een van die probleme waarmee onderwysers, en ook ander opleiers, deesdae te kampe het, is die oorvloed van inligting wat op netwerke beskikbaar is. Daar moet altyd sorg gedra word dat die inligting waar en korrek is, want dit kan maklik verander wanneer nuwe inligting op netwerkplatforms verskyn. Onderwysers moet ook weet wat presies onderrig moet word, aangesien so baie inligting op webwerwe beskikbaar is. In die konnektivistiese omgewing bly onderwysers steeds belangrik om aan leerders ondersteuning te gee oor watter inligting hulle moet behou (Tedla 2012:200).

Alhoewel daar kritiek bestaan jeens konnektivisme, is dit tans die enigste leerteorie wat die opvoedkundige gebruik van IKT in die huidige netwerkgemeenskap onderskryf. Die ontstaan van konnektivisme beteken nie dat die vorige leerteorieë verdwyn nie, aangesien die beginsels en tegnieke van konnektivisme juis uit die bestaande leerteorieë ontwikkel het.

Konnektivisme kan nie in die huidige tydvak tot sy volle reg kom in al die skole in Suid-Afrika nie. Een van die beginsels van konnektivisme is dat kennis gelyk tussen verskillende netwerke versprei moet word. Dit beteken dat die leeromgewings vir alle leerders oor die tipe tegnologie moet beskik wat nodig is vir konnektivistiese leernetwerke. Dit sal nie op die oomblik in alle skole in Suid-Afrika gebruik kan word nie. Navorsing oor die gebruik van IKT in skole het die gebrek aan IKT-infrastruktuur, onvoldoende opleiding van personeel, onvoldoende ondersteuningsdienste, 'n gebrek aan kommunikasie, lae vlakke van selfvertroue en kundigheid en 'n gebrek aan netwerkgeletterdheid as sommige van die struikelblokke in die gebruik daarvan in skole uitgewys (Mlitwa 2006:11). Die meeste van die faktore wat Mlitwa meld, het ook in die navorsing waarop hierdie artikel berus, na vore getree.

Maar uit die navorsingdata wat in dié artikel beskryf word, het die manier waarop onderwysers reeds betrokke is by konnektivisme ook duidelik gespreek. Sommige van die onderwysers het genoem dat van hulle leerders in groepsverband op rekenaars en op die internet werk. Dit kan beskou word as die vertrekpunt van konnektivisme. Van die onderwysers het dit duidelik laat blyk dat hulle konnektivisme gebruik vir hulle persoonlike en professionele groei. Sommige onderwysers het aangedui dat hulle deelneem in gemeenskappe van leer wat help om hulle te bemagtig met kennis en inligting wat vir hulle waardevol in hul beroepe is. Die gemeenskappe van leer het die onderwysers ook gehelp om die magdom kennis wat op webwerwe is te beoordeel en om met behulp van ander persone binne die gemeenskap van leer, goeie en korrekte inligting te verkry.

\section{Slot}

Uit die inligting uit die navorsing wat by skole gedoen is, blyk dit dat baie van die probleme wat onderwysers met die gebruik van IKT in skole gemeld het, verband hou met die infrastruktuur wat nodig is om IKT suksesvol te gebruik. Tegniese ondersteuning en die opleiding van alle onderwysers is faktore wat ook vermeld is, maar wat die aandag van die bestuur van die skole en die Departement van Basiese Onderwys behoort te kry. Wat die laaste drie punte betref wat uit die navorsing geblyk het, kan kennis van die leerteorieë wat die gebruik van IKT in skole beïnvloed, wel bydra dat IKT met meer sukses in skole gebruik word. Hierdie drie punte is: Ouers se samewerking om hul kinders klein opdragte op hul slimfone te laat uitvoer; die motiveringswaarde van die gebruik van IKT in die klaskamer; en onderwysers se persoonlike en professionele ontwikkeling omdat hulle deur middel van IKT toegang kan kry tot opgedateerde inligting en ook lede van gemeenskappe van leer kan word.

\section{Aanbevelings}

Behaviourisme het 'n plek wanneer IKT gebruik word vir onderrig in skole, veral wanneer dit by die aanleer van parate kennis kom wat leerders eenvoudig moet ken, soos byvoorbeeld spelwoorde en tafels. 'n Ander voordeel van die gebruik van behaviourisme en IKT is dat programme soos byvoorbeeld dié vir spelling en die dril van wiskundige beginsels onmiddellik terugvoer gee. Dit het groot motiveringswaarde en kan veral in die laer grade met sukses gebruik word. Maar behaviourisme alleen moet nie die teoretiese vertrekpunt wees wanneer leerders onderrig word nie. Onderwysers behoort tydens IKT-onderrig gebruik te maak van 'n samestelling van die verskillende beginsels van leerteorieë waarmee hulle vertroud is. Watter beginsels gedurende IKT-onderrig gebruik sal word, sal afhang van die leeruitkomste wat vir 'n les of lesse beplan word en sekerlik ook van die tipe tegnologie wat in 'n skool beskikbaar is. Dit is derhalwe noodsaaklik dat onderwysers kennis moet dra, nie net van behaviourisme nie, maar ook van konstruktivisme en konnektivisme.

Onderwysers behoort opgelei te word sodat hulle weet wanneer om met behulp van IKT 'n konstruktivistiese benadering in hulle klaskamers te volg. Sodoende word hulle die fasiliteerders van hul leerders se leerproses wat in ooreenstemming is met die benaderings wat in die nuwe skoolkurrikula aanbeveel word. IKT kan dan ook gebruik word om aan te pas by die individuele leerbehoeftes van spesifieke leerders. Die groot motiveringswaarde wat IKT kan hê, word dan benut.

Sommige van die respondente wat aan die navorsing deelgeneem het, het reeds gebruik gemaak van konnektivisme wat die gebruik van IKT betref. Onderwysers behoort derhalwe opgelei te word om die waarde van IKT en konnektivisme te besef en in te span in die onderrigleersituasie. Leerders kan in groepsverband werk en hulle 
kan opgelei word om hulle kennis nie net op nasionale vlak nie, maar ook op internasionale gebied te verbreed. Ander belangstellendes, soos die ouers en voogde van leerders, kan ook deel uitmaak van die leerders se groepe en van hulle gemeenskappe van leer. Alle onderwysers behoort ook kennis te dra van die waarde wat konnektivisme moontlik vir hulle persoonlike en professionele groei as onderwysers kan inhou.

Daar word aanbeveel dat onderwysers deel moet wees van 'n gemeenskap van leer om sodoende die geleentheid te kry om op enige plek en enige tyd te leer en kennis uit te ruil met mense wat dieselfde belangstellings het (Kop \& Hill 2008:6; Wang 2008:415). Dit is veral noodsaaklik op 'n vakgebied soos Rekenaarwetenskap omdat IKT voortdurend aan die verander en ontwikkel is. Hierdie interaksie met ander mense kan daartoe lei dat die leer- en onderrigproses beïnvloed kan word, nie net deur kognitiewe faktore nie, maar ook deur emosionele faktore. Leer in die konnektivistiese model geskied juis deur die benutting van beide die kognitiewe en die affektiewe domeine. Dit is belangrik om in die onderrig- en leersituasie voorsiening te maak vir kognisie, sowel as vir emosies, want beide is belangrik om die leerproses te bevorder.

\section{Erkenning \\ Mededingende belange}

Die outeurs verklaar hiermee dat hulle geen finansiële of persoonlike verbintenis het met enige party wat hulle nadelig of voordelig kon beïnvloed het in die skryf van hierdie artikel nie.

\section{Outeursbydrae}

S.S.M. het die aanvanklike navorsing gedoen en A.J.H. het leiding geneem in die interpretasie van die data ten opsigte van die leerteorieë en het gehelp met die konseptualisering van die artikel.

\section{Literatuurverwysings}

Bailey, C.A., 2007, A guide to qualitative field research, 2nd ed., Sage, Thousand Oaks, CA.

Belford, R.E., 2013, 'Review of learning theories: An educational perspective, 6th edition', Journal of Chemical Education 90, 150-151.

Brooks, A.E., 2015, 'Using connectivism to guide information literacy instruction with tablets', Journal of Information Technology 9(2), 27-36. https://doi.org/10.11645/ 9.2.2007
Brown, T.H., 2006, 'Beyond constructivism: Navigationism in the knowledge era', On the Horizon 14(3), 108-120. https://doi.org/10.1108/10748120610690681

Dede, C., 2008, 'Theoretical perspectives influencing the use of information technology in teaching and learning', in J. Voogt, G. Knezek (eds.), International Handbook of Information Technology in Primary and Secondary Education, pp. 43-62. Springer, United Sates.

Duke, B., Harper, G. \& Johnston, M., 2013, 'Connectivism as a digital age learning theory', International HETL Review, special issue, 4-13.

Dunaway, M.K., 2011, 'Connectivism: Learning theory and pedagogical practice for networked information landscapes', Reference Services Review 39(4), 675-685. https://doi.org/10.1108/00907321111186686

Engelbrecht, A., 2013, 'Multi-level teaching: An introduction', in A. Engelbrecht \& H. Swanepoel (eds.), Embracing diversity, 33-49, Cape Town, Juta.

Ertmer, P. \& Newby, T.J., 2013, 'Behaviorism, cognitivism, constructivism: Comparing critical features from an instructional design perspective', Performance Improvement Quarterly 26(2), 43-71. https://doi.org/10.1002/piq.21143

Eze, R.I. \& Olusola, E., 2013, 'The teachers and the use of ICT for professional development', viewed 12 June 2016, from http://ictfoeafrica.org

Felix, U., 2005, 'E-learning pedagogy in the third millennium: The need for combining social and cognitive constructivist approaches', ReCALL 17(1), 85-100. https://doi. org/10.1017/S0958344005000716

Garcia, E., Brown, M. \& Elbeltagi, I., 2013, 'Learning within a connectivist educational collective blog model: Case study of UK higher education', viewed on 21 February 2017, from http://www.ejel.org

Gunter, G.A. \& Gunter E., 2015, Teachers discovering computers: Integrating technology in a changing world, 8th ed., Cencage Learning, Boston, MA.

Kler, S., 2014, 'ICT integration in teaching and learning: Empowerment of education with technology', viewed on 07 September 2014, from http://dspace.chitkara. edu.in/jspui/bitstream/1/473/1/22019_IlE_Kler.pdf

Kop, R. \& Hill, A., 2008, 'Connectivism: Learning theory of the future or vestige of the past?', The International Review of Research in Open Distance Learning. E-journa 9(3), viewed on 12 December 2014, from http://www.irrodl.org/index.php/irrodl/ article/view/523/1103

Krauss, S.E., 2005, 'Research paradigms and meaning making: A primer', The Qualitative Report 10(4), 758-770.

Lee, J., 2011, Adapting education to the information age, white paper, Korea Education and Research Information Service, viewed on 20 July 2015, from http:// englishkeris

Magano, M. \& Ramnarain, U., 2015, Including the excluded: Educating the vulnerable in the 21st century, Pearson, Cape Town \& Midrand, South Africa.

Mdlongwa, T., 2012, 'Information and Communication Technology (ICT) as a means of enhancing education in schools in South Africa: Challenges, benefits and recommendations', Africa Institute of South Africa Policy Brief 80, viewed on 15 January 2015, from http://www.ai.org.za

Mlitwa, N.B.W., 2006, 'The status of ICT access and use in South African schools: Comparing the rural and urban schools in the Mpumalanga Province', viewed on 14 July 2016, from http://emerge2008.net/access/content/group/Mlitwa/access

Place, J., 2016, 'Teaching reading and viewing', in A. Hugo (ed.), Teaching English as a first additional language in the intermediate and senior phase, pp. 51-69, Cape Town, Juta.

Siemens, G., 2004, Connectivism: A learning theory for the digital age, viewed on 08 June 2016, from http://www.elearnspace.org

Tedla, B.A., 2012, 'Understanding the importance, impacts and barriers of ICT on teaching and learning in East African countries', IJeLS 2(3/4), 199-207. https://doi. org/10.20533/ijels.2046.4568.2012.0025

Taole, M., Mukhari, S. \& Hugo, A.J., 2016, 'The use of ICT in the language classroom', in A. Hugo (ed.), English as a first additional language in the intermediate and senior phase, Cape Town, Juta.

Vygotsky, L.S., 1978, Mind in society: The development of higher psychological processes, Harvard University Press, Cambridge, MA.

Wang, Q., 2008, 'A generic model for guiding the integration of ICT into teaching and learning', Innovations in Education and Teaching International 45, 411-419. https://doi.org/10.1080/14703290802377307 